\title{
Utilization of estimated rainfall as an early warning system before flash flood event
}

\author{
Fara Diva Claudia ${ }^{1}$, Cecylia Putri Mawarni ${ }^{2}$, Kadek Krisna Yulianti ${ }^{3}$, Paulus Agus \\ Winarso ${ }^{4}$ \\ ${ }^{1,2,3,4}$ School of Meteorology, Climatology, and Geophysics (STMKG) \\ Jl. Perhubungan 1 No 5 South Tangerang Banten \\ ${ }^{1}$ Email : claudiafaradiva@gmail.com
}

Received 10 August 2018, Revised 18 September 2018, Published 30 September 2018

\begin{abstract}
On October 10, 2018 there has been extreme weather in the form of heavy rain accompanied by lightning in Tanah Datar District, West Sumatra. This extreme weather caused flash floods and landslides that killed many people. Therefore, by using remote sensing data in the form of radar and satellite as well as WRF modeling (Weather Research and Forecasting) the authors conducted analysis of heavy rainfall events to determine the estimated rainfall and atmospheric dynamics during the occurrence of flash floods and landslides. WRF modeling is used to determine the condition of atmospheric lability. For the calculation of rainfall estimation, the method used is the Convective Stratiform Technique (CST) method that utilizes satellite data and the Z-R relation selection method that utilizes radar data. Then the calculation results from each method are verified using observation data. Relative bias shows the CST method and the selection of Z-R relations tend to be overestimate, but has a very high correlation value with observation data. Information on rainfall estimation and atmospheric dynamics is expected to be used to provide early warnings aimed at minimizing losses from the impact of disasters.
\end{abstract}

Keyword : Flash flood, CST, rainfall estimation, relation of Z-R

\section{Introduction}

On October 10, 2018, based on the BPBD (Badan Penanggulangan Bencana Daerah) of West Sumatra report there have been flash floods and landslides in Tanah Datar District. This report is equipped with information that the flash flood that occurred was caused by heavy rains that have occurred in the last few days. Flash floods and landslides are hydrometeorological hazard that can kill many people and property losses, so mitigation efforts are needed to minimize these disasters. One way to mitigate hydrometeorological disasters is by making early warnings.

The accurate and real time rainfall information is needed in various fields such as floods, landslides and droughts in research related to the hydrological cycle (Suwarsono et al., 2009; Joyce et al., 2004; Hong et al., 2007). To produce accurate flood data, accurate rainfall is also needed. Accurate rainfall data can be obtained through direct observation using rain gauge. However, currently monitoring rainfall has not covered all areas on the surface of the earth. This is due to limited rainfall observation points. The 
existence of these limits will certainly be a limitation for users in obtaining rainfall information. Therefore, to make flood early warnings in an area used rainfall estimation data from weather satellites.

Weather satellite data is one solution to overcome the problem of limited observation data. In addition, weather satellite data has spatial and temporal resolution that is suitable for making predictions as early warning information. This is because weather satellites have a very wide range of observations with a high enough frequency of observation and data that can be obtained up-to-date and are free of charge. One method of estimating rainfall based on cloud temperatures using weather satellites is the Convective Stratiform Technique (CST) method. CST is a method of precipitation estimation with convective group and stratiform separation found by Adler and Negri (1988). This study aims to determine the estimated rainfall that is useful for making early warning of flood events. According to Andani and Endarwin (2017), CST method can be applied for estimating rainfall in Pontianak. The correlation of CST and rainfall of Hellman observation showed a good result. The result also shown a high correlation in Surabaya (Putra and Andani, 2016). While, on using radar reflectivity in Surabaya, correlation between reflectivity and rainfall estimation have a good result by using CAPPI. Based on this, an early warning was made for the Tanah Datar District using satellite data and gematronic weather radar based on October 10, 2018 events.

\section{Data and Methods}

\subsection{Location and Time of Research}

This research was conducted in Tanah Datar which is located at $0.52^{\circ}$ LS and $100.81^{\circ} \mathrm{BT}$ and Padang Pariaman at $0.53^{\circ} \mathrm{LS}$ and $100.25^{\circ} \mathrm{BT}$. The time of research was during the occurrence of flash floods and landslides by taking case studies on 8-12 October 2018.

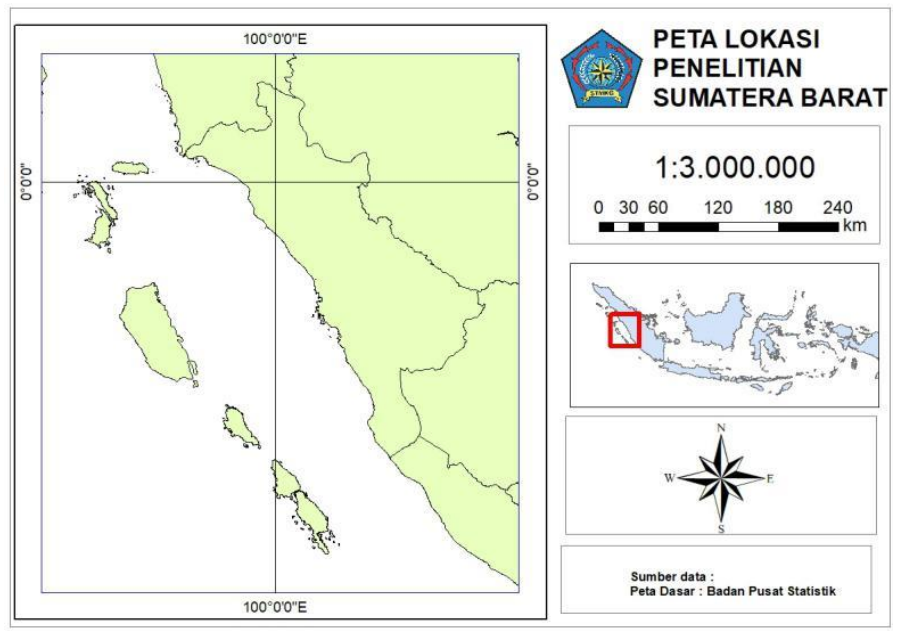

Figure 1. Map of the Research Location 


\subsection{Data}

The data used in this study include:

1. Observation data of data accumulated daily rainfall obtained from the results of measurement with rain gauge from the station

2. IR-1 channel data of Himawari satellite imagery in the PGM and DAT format obtained from http://weather.is.kochi-u.ac.jp/sat/GAME and http: //weather.is.kochiu.ac.jp/sat/CAL.

3. The radar data from weather radar in Minangkabau Meteorology station in Padang.

4. FNL reanalysis data from rda.ucar.edu with spatial resolution $0.25^{\circ} \times 0.25^{\circ}$ and temporal resolution 6 hours.

\subsection{Methods}

\subsubsection{CST Methods}

Satellite data IR-1 channel is processed with the image processor software. Estimation by the CST method is done by calculating the parameter slope (S) with the following equation (Andi, 2007; Endarwin, 2014):

$$
S=k\left(T_{i-2, j}+T_{i-1, j}+T_{i+1, j}+T_{i+2, j}+T_{i, j-2}+T_{i, j+1}+T_{i, j+1}+T_{i, j+2}-8 T_{i, j}\right)
$$

Explanation:

$\mathrm{S} \quad=$ slope parameter $(\mathrm{K})$

$\mathrm{T}=$ Cloud Brightness Temperature $(\mathrm{TBB})(\mathrm{K})$

$i$ dan $j=$ position of the pixel value where $S$ is calculated

$\mathrm{k} \quad=$ constant $=0,125$

Slope values are used for classification of convective cloud types or not. Separation of the convective core and stratiform in cloud components is carried out in this method. Estimated rainfall every hour using the CST method is done by the following equation:

Curah Hujan $(\mathrm{mm})=\mathrm{C}($ Acs/A) $\mathrm{T}$ Rc

Explanation:

$\mathrm{C} \quad=$ number of convective cell

Acs = Convective / statiform area $(\mathrm{km} 2)$

A = average area covered by each pixel $(\mathrm{km} 2)$

$\mathrm{T}=$ average estimation period (hour)

Rcs = convective / statiform rainfall intensity ( $\mathrm{mm} /$ hour)

\subsubsection{Z-R Relation}

Radar estimates the rainfall by utilizing the reflectivity $(Z)$ and rain rate $(R)$ relation or commonly known as the Z-R relation. The relation of Z-R is mathematically expressed in equation (3)

$\mathrm{Z}=\mathrm{a} \mathrm{Rb}$

Value of ' $a$ ' indicates the average size of the drop diameter in sample volume and $b$ represents the change in drop size in the sample volume (SELEX, 2013). Raw radar data 
from Minangkabau meteorology station is processed using the Rainbow application precisely on the RainDART application. Raw radar data is processed into a product that will be used to estimate rainfall. The step taken is to make a rainfall estimation input product consisting of PPI, CAPPI, CMAX and SRI. Setting the relation of ZR as a rainfall conversion equation is done on SRI products, while the ZR relation that will be used in this study is the Marshall-Palmer ZR relationship $(A=200, b=1.6)$, WSR-88D Convective $(A=300, b=1.4)$, Rosenfeld-Tropical $(A=250, b=1.2)$, and Sekine $(A=$ $286, b=1.6)$.

\subsubsection{Verification}

Correlation coefficient is a number that states the size of a relation between variables (Sudjana, 1996). A value of $C$ that approaches 1 or -1 shows a very close relationship. The correlation coefficient value in this study was obtained by comparing the estimated rainfall data using the CST method and the Z-R relation to the observation data.

\section{Result and Discussion}

\subsection{Weather Parameters of WRF Output}

\subsubsection{Surface Wind Streamline Analysis}

In Figure 3, a map of horizontal wind components $\mathrm{u}$ and $\mathrm{v}$ is displayed in October 811, 2018. Wind patterns $\mathrm{u}$ and $\mathrm{v}$ in October 8 show air flow from various directions leading to areas in Tanah Datar, so that wind convergence regions are formed. The convergence of horizontal winds causes air to rise, indicating a vertical movement that supports the growth of convective clouds.
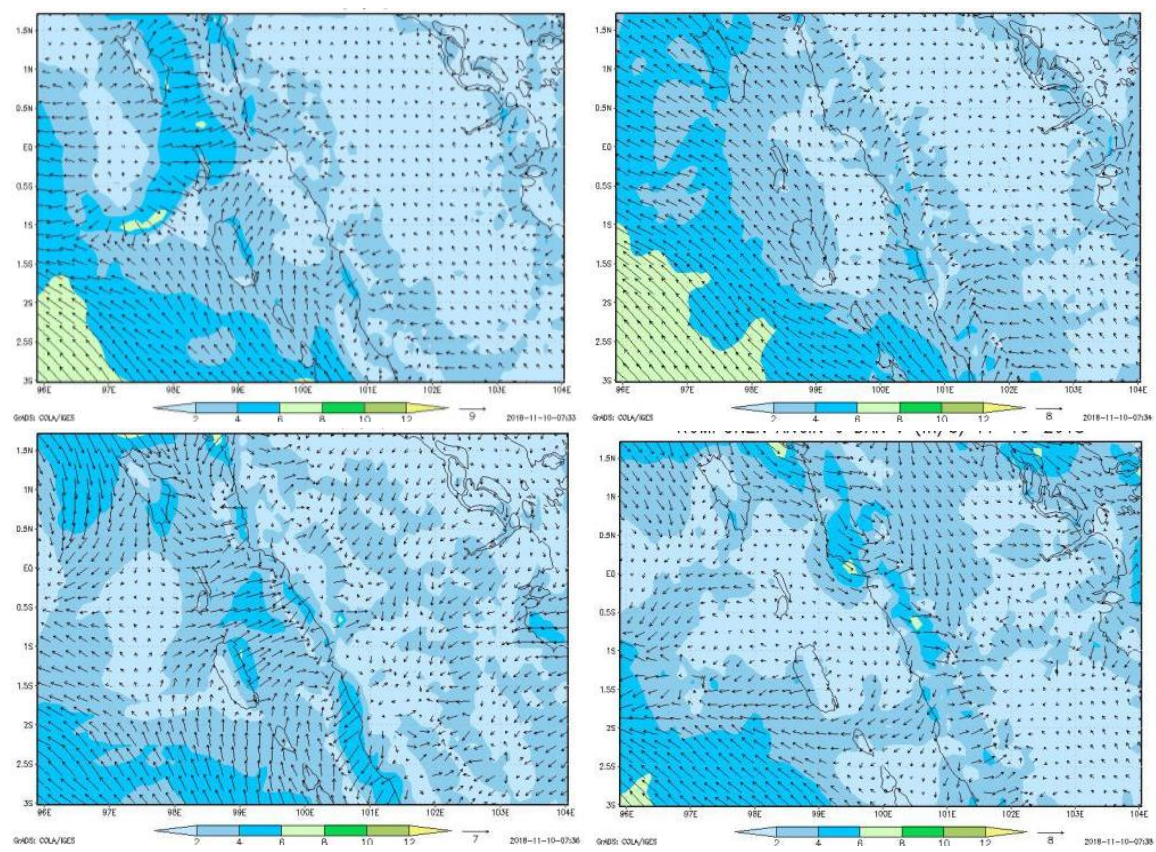

Figure 3. Horizontal wind components $\mathrm{u}$ and v October 8-11 2018 
In October 9, 2018 the dominant horizontal wind direction pattern from the northeast to Tanah Datar. In addition, there is air flow from the southwest so that there is an extended convergence in the area of Tanah Datar. This convergence area that extends indicates that there is a convective cloud whose horizontal extent. Whereas, horizontal wind patterns $\mathrm{u}$ and $\mathrm{v}$ on October 10, there is outflow in Tanah Datar. The air flow comes from the downdraft convective cloud which is in the dissipation phase. Downdraft from convective clouds can form a cold pool that can form new convective cloud cells when atmospheric conditions support. The horizontal wind pattern in 11 October 2018 show a pattern of convergence in Tanah Datar. The convergence area forms an elongated pattern that shows the convective cloud. The formation of convective clouds shows that the cold pool in October 10, 2018 has developed into a new convective cloud cell. Convective cloud cells with elongated patterns can indicate the phenomenon of squall lines that cause heavy rainfall.

\subsubsection{Vertical Profile of Relative Humadity (RH)}

From figure 4 it can be seen the vertical profile of Relative Humidity (RH). The vertical RH profile is used to see the air humidity vertically. If the RH is more than $60 \%$, then this can be implicated as the presence of cloud cover in the area. Based on the $\mathrm{RH}$ profile on October 8, 2018 there is a high $\mathrm{RH}$ value (>60\%) up to $500 \mathrm{mb}$ in Tanah Datar. A high RH value of up to $500 \mathrm{mb}$ indicates the potential for heavy rainfall. On October 9, 2018 the RH value at the research location still shows above $60 \%$ to a layer of $500 \mathrm{mb}$ so that there is still convective cloud. This RH value is supported by a pattern of wind convergence which causes vertical motion. Vertical movement brings moisture to the top layer so that the air becomes moist.

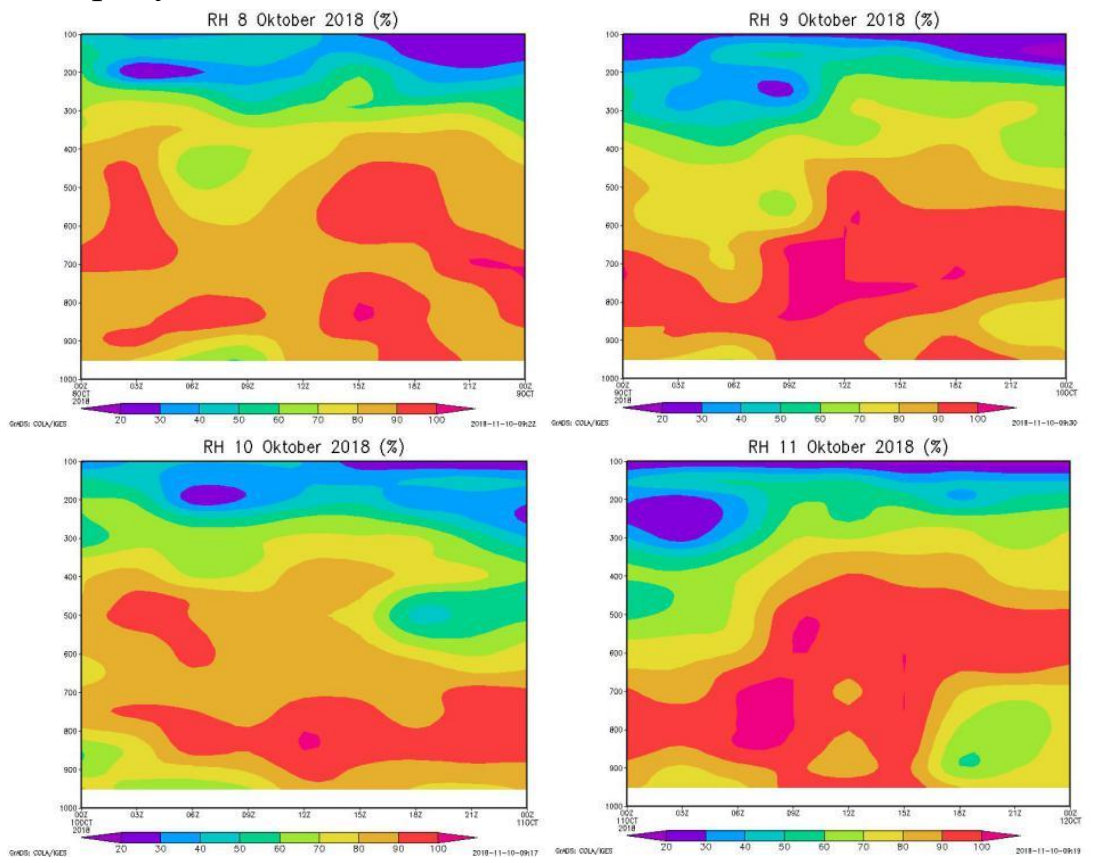

Figure 4. Vertical profile of Relative Humadity (RH) on October 8-11, 2018 
On October 10, 2018 the RH value is relatively high up to $500 \mathrm{mb}$ until around at 17.00 UTC. Whereas at $17.30 \mathrm{UTC}$ the RH value at $500 \mathrm{mb}$ has decreased $(<60 \%)$. This decrease of RH value indicates a reduction in the amount of water vapor at the $500 \mathrm{mb}$ layer caused by a lack of water supply through an upward vertical motion or updraft. This is in accordance with the wind pattern on October 10, 2018 which shows a divergence pattern due to the downdraft so that the water vapor in the upper layer decreases. On October 11, 2018 an increase the value of $\mathrm{RH}(>60 \%)$ to a layer of 500 $\mathrm{mb}$ at $03.00 \mathrm{UTC}$. The RH value at the $500 \mathrm{mb}$ layer continues to increase to $>90 \%$ which indicates very humid air. This shows the presence of very high water vapor and has the potential of heavy rainfall. The $\mathrm{RH}$ vertical profile at the scene is strongly influenced by surface wind patterns. The divergence pattern of surface wind causes a vertical or updraft motion that brings water vapor to the upper layer which will condense to form convective clouds that can produce rain. The RH decline on October 10,2018 shows that water vapor has dropped to heavy rain and cloud dissipation.

\subsubsection{Vertical Profile of $C A P E$}

In Figure 5 shows the vertical profile of the CAPE (Convective Available Potential Energy) index on October 8-11 2018. Convective Available Potential Energy (CAPE) is measure of the amount of energy available for convection, indicate potential for severe weather. According to (Zakir, 2018) CAPE values in the range of 500-2000 J / kg indicate the potential for strong or severe storm. The vertical profile of CAPE on October 8, 2018 shows a CAPE value reaching $1400 \mathrm{~J} / \mathrm{kg}$ at around 13.00 UTC. Furthermore, for October 9, 2018 the CAPE value reaches $2000 \mathrm{~J} / \mathrm{kg}$ at around 05.00 UTC where the value indicates a strong storm of severe storms (Zakir, 2018).

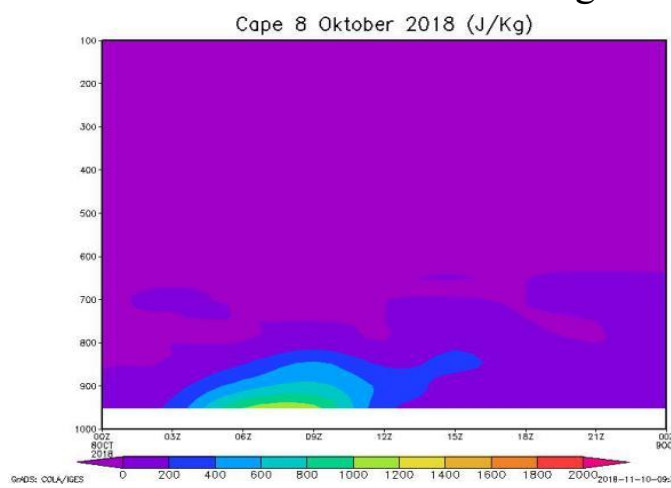

Cape 10 Oktober $2018(\mathrm{~J} / \mathrm{Kg})$

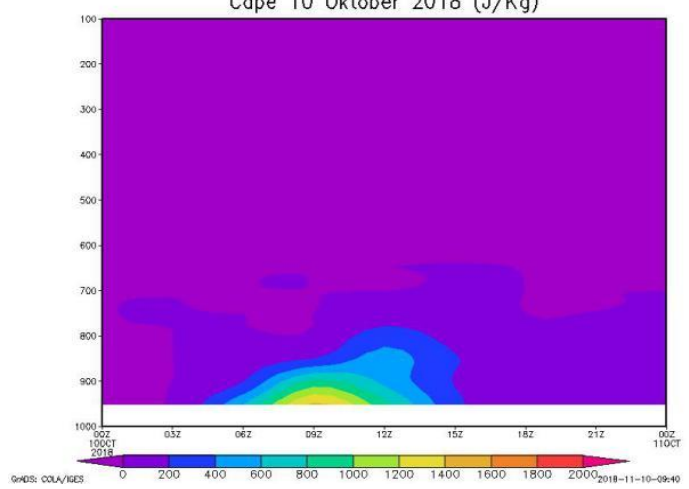

Cape 9 Oktober $2018(\mathrm{~J} / \mathrm{Kg})$

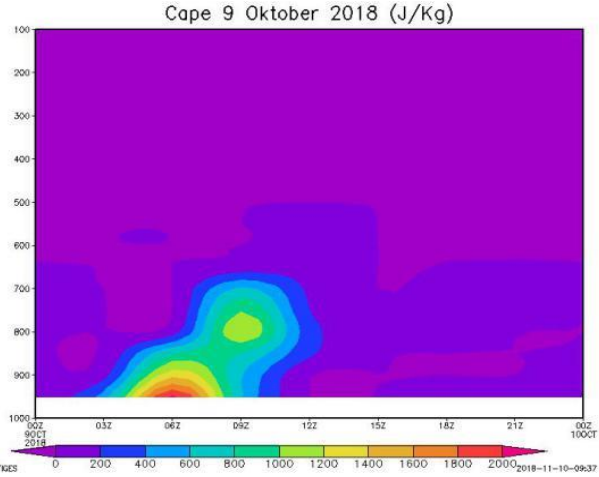

Cape 11 Oktober $2018(\mathrm{~J} / \mathrm{Kg})$

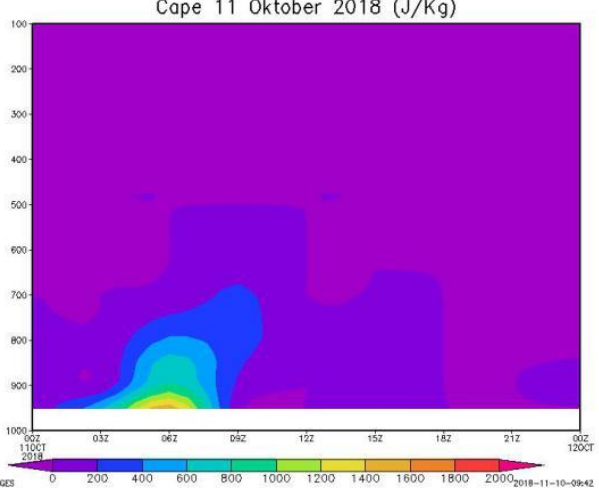

Figure 5. Vertical profile of CAPE on October 8-11 2018 
On October 10, 2018 the highest CAPE value reaches $1400 \mathrm{~J} / \mathrm{kg}$ and on October 11, 2018 the highest CAPE value also reaches $1400 \mathrm{~J} / \mathrm{kg}$. From the CAPE value, it can be seen that the highest CAPE occurred on October 9, 2018 showing a strong storm cloud that caused heavy rain causing flash floods and landslides on October 10, 2018.

\subsection{Estimated Rainfall Using CST}

This CST method will show rainfall estimates on October 8 and 9, 2018. The selection is based on information on the occurrence of flash floods and landslides on October 10, 2018, so that rainfall estimates used for early warning take time before the event.

\subsubsection{Estimated Rainfall October 8, 2018}
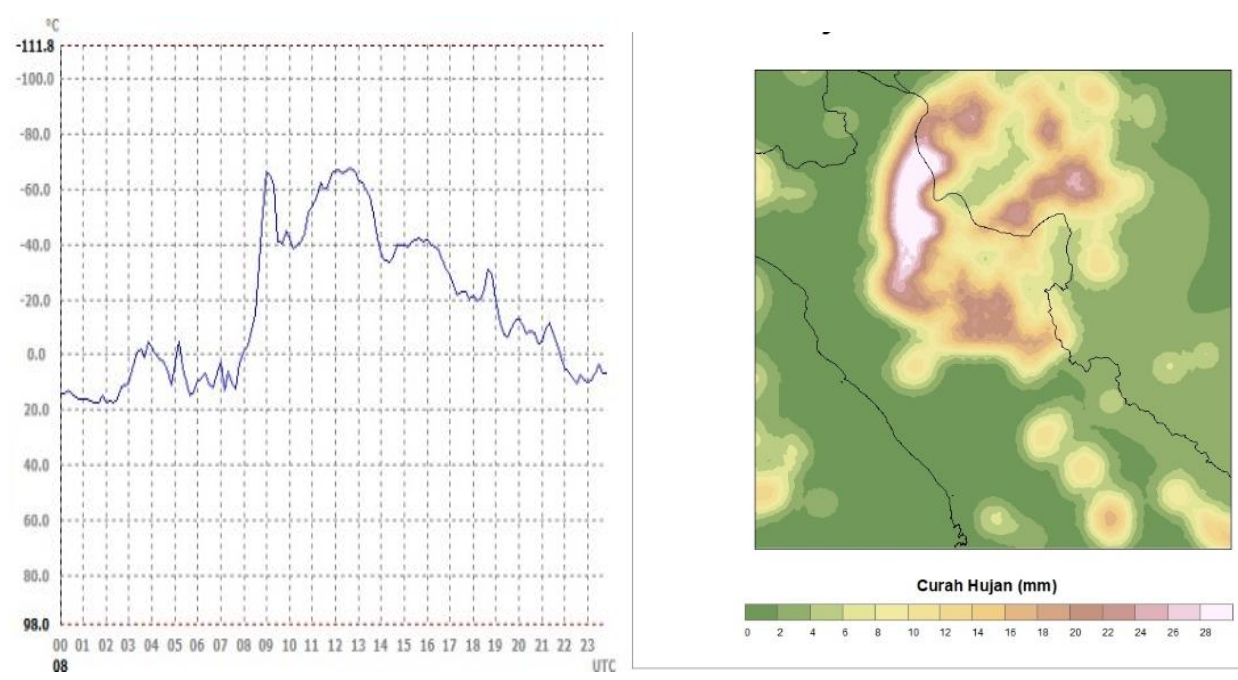

Figure 6. Time series top cloud temperature and rainfall estimation (13.00 UTC)

October 8, 2018

On October 8, 2018, there was heavy rainfall. According to Himawari-8 satellite data, it is seen that there is a cloud growth which is marked by an increase in the temperature of the top cloud. Temperatures of cloud brightness that have the potential causes high rainfall range from $195-235$ equivalent to $-78^{\circ} \mathrm{C}$ to $-40^{\circ} \mathrm{C}$ (Parwati et al., 2008). In the area around Tanah Datar there is an increase in high temperatures of top cloud from at 08.00 UTC or 15:00 LT. The highest top cloud temperature is $60.5{ }^{\circ} \mathrm{C}$ at 12.00 UTC.

With the CST method, as shown above, a very large rainfall distribution covers Agam, Tanah Datar, and Limapuluh Kota Districts. The highest estimated rainfall is $40.48 \mathrm{~mm}$. Rainfall with this value is heavy rainfall. At other hours the intensity of rainfall is also high. The rainfall intensity of 9, 10, 11, 13 and 14 UTC is $20.58 \mathrm{~mm}$, $34.14 \mathrm{~mm}, 34.14 \mathrm{~mm}, 40.48 \mathrm{~mm}$ and $34.14 \mathrm{~mm}$ respectively. 


\subsubsection{Estimated Rainfall October 92018}

From the time series graph the top cloud temperature reaches $60.50{ }^{\circ} \mathrm{C}$ at $12.00 \mathrm{UTC}$. At other hours the temperature of the top cloud is very low, below $-40{ }^{0} \mathrm{C}$. October 9 , 2018 at 12.00 UTC the rainfall is still high. The distribution of rainfall with a value of $16-30 \mathrm{~mm}$ is in Limapuluh Kota with a maximum intensity of $31.51 \mathrm{~mm}$. At 13.00 UTC the rainfall slowly decreased to $29.17 \mathrm{~mm}$.
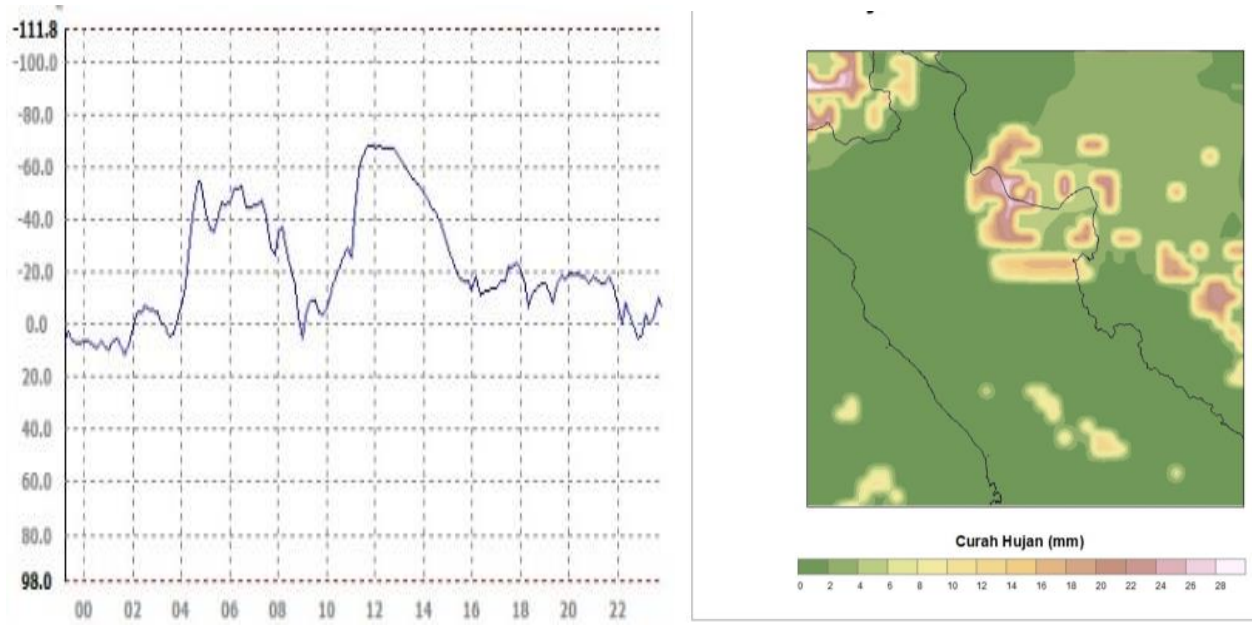

Figure 7. Time series of top cloud temperature and rainfall estimation (12:00 UTC) October 9, 2018

\subsubsection{CST Rainfall Correlation with Observation}

On October 8, 2018 measured rainfall using observations in West Sumatra, the highest was $34.6 \mathrm{~mm}$. The intensity of rainfall has a lower value than the estimated maximum rainfall intensity using the CST method with a value of $40.48 \mathrm{~mm}$. Whereas on October 9, 2018 the estimated CST rainfall is $31.51 \mathrm{~mm}$. This intensity is lower than the observation rainfall of $65 \mathrm{~mm}$.

\subsection{Estimated Rainfall Using Relation of $Z-R$}

The rainfall estimation method using the relation Z-R is shown for the Padang Pariaman.

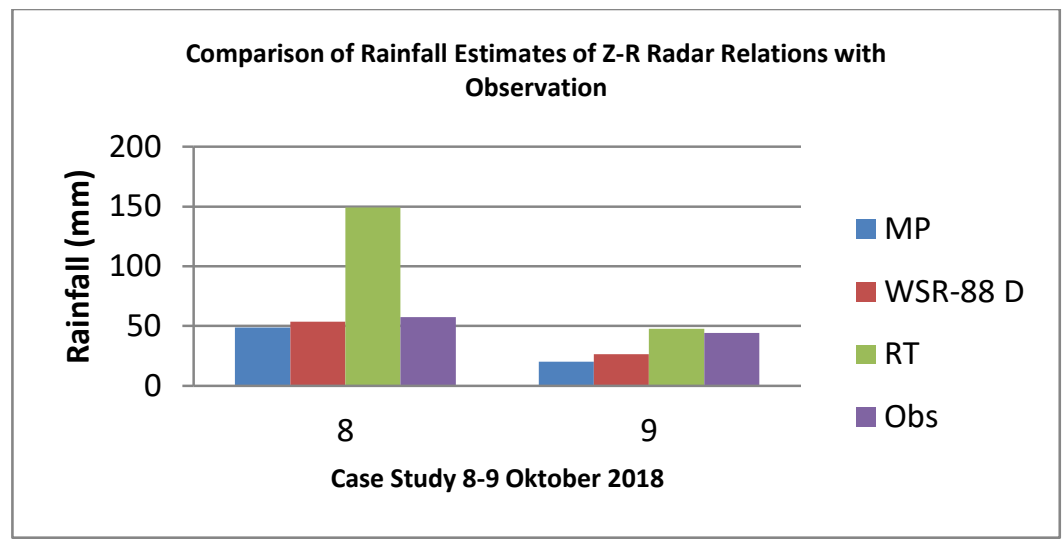

Figure 7. Graph of comparison of estimated rainfall results with observation results in Padang Pariaman 
Table 1. Value of rainfall correlation results from estimates with radar products at rain

\begin{tabular}{ccccc}
\multicolumn{5}{c}{ gauge } \\
\hline Date & MP & WSR-88 D & RT & Observation \\
\hline 8 October 2018 & $48,71 \mathrm{~mm}$ & $53,46 \mathrm{~mm}$ & $96,2 \mathrm{~mm}$ & $57,3 \mathrm{~mm}$ \\
9 October 2018 & $20,27 \mathrm{~mm}$ & $26,44 \mathrm{~mm}$ & $47,62 \mathrm{~mm}$ & $44 \mathrm{~mm}$ \\
Correlation & 1 & 1 & 1 & \\
\hline
\end{tabular}

The maximum rainfall observed in Padang Pariaman on October 8, 2018 reached $57.3 \mathrm{~mm}$ while the estimation results showed a maximum value of $96.2 \mathrm{~mm}$ from RTSRI products. For MP-SRI products shows a value of $48.71 \mathrm{~mm}$, and for WSR-88D-SRI products shows a value of $53.46 \mathrm{~mm}$. The maximum rainfall observed in Padang Pariaman on October 9, 2018 reached $44 \mathrm{~mm}$ while the estimation results showed a maximum value of $47.62 \mathrm{~mm}$ from RT-SRI products. MP-SRI products show a value of $20.27 \mathrm{~mm}$, and for the WSR-88D-SRI product, the value is $26.44 \mathrm{~mm}$.

Overall, it can be seen that the estimated rainfall generated by the radar on October 8 , 2018 to October 9, 2018 is an underestimate for the selection of MP-SRI ZR and WSR88D-SRI, while the ZR RT-SRI selection is overestimate with the correlation values is 1 .

\section{Conclusion}

The atmospheric conditions on October 8, 2018 based on wind patterns $\mathrm{u}$ and $\mathrm{v}$ indicate the existence of convergence in the area of Tanah Datar District which shows the convective growth area. This is supported by high CAPE values reaching $1400 \mathrm{~J} / \mathrm{kg}$ and $\mathrm{RH}$ values $>80 \%$ to layers of $500 \mathrm{mb}$. From the three parameters, it can be concluded that the atmospheric conditions before the flood are unstable.

Estimated rainfall using the CST method is not good for the West Sumatra area. On October 8, 2018 estimates of overestimate rainfall compared to observations. Whereas for October 9, 2018 the estimated rainfall is underestimated. This is the same as rainfall estimation using the Z-R relation selection method using radar, ie on October 8, 2018 the estimates obtained are overestimate, while on October 9, 2018 the estimates obtained are underestimated. However, rainfall estimation using the Z-R relation selection method has a high correlation value, while rainfall estimation using the CST method has a low correlation value.

\section{Acknowledgements}

This research was supported by School of Meteorology Climatology and Geophysics. We thank our lecturer Dr. Paulus Agus Winarso who provide insight and expertise that greatly assisted research.

\section{References}

Adler, H.F., and Negri, A. J. (1988), A Satellite Infrared Technique to Estimate to Estimate Tropical Convective and Stratiform Rainfall. Journal of Applied Meteorology, 27, 30-51. 
Andani, A.J.P. (2016). Kajian Penerapan Estimasi Curah Hujan Per Jam Memanfaatkan Metode Convection Stratiform Technique (CST) dan Modified Convective Stratiform Technique (mCST) di Pontianak. Jurnal Meteorologi Klimatologi dan Geofisika, 3(3), 9-20.

Andi, I. (2007). Estimasi Curah Hujan Beberapa Kota di Indonesia Menggunakan Data MT-SAT Kanal Inframerah (IR1). Thesis, Fakultas Ilmu dan Tekonlogi Kebumian: Institut Teknologi Bandung.

Endarwin. (2014). Modifikasi Convective Stratiform Technique dengan Kombinasi Data Satelit Gelombang Mikro Pasif dan Inframerah untuk Estimasi Curah Hujan di Indonesia. Disertation, Program Studi Sains Kebumian Institut Teknologi Bandung Bandung.

Fatoni, A. R. (2016). Kajian Tingkat Akurasi Produk Radar Cuaca dalam Melakukan Estimasi Curah Hujan di Surabaya. Jurnal Meteorologi Klimatologi dan Geofisika, Tangerang Selatan.

Hong, Y., R.F. Adler, A. Negri, and Huffman, G.J. (2007). Flood and Landslide Applications of Near Real-time Satellite Rainfall Estimation. Journal of Natural Hazards, doi: 10.1007/s11069- 006-9106-x.

Joyce, R. J., J. E. Janowiak, P. A. Arkin, and P. Xie. (2004). CMORPH: A Method that Produces Global Precipitation Estimates from Passive Microwave and Infrared Data at High Spatial and Temporal resolution. J. Hydromet, 5, 487- 503.

Putra, R.M. and Andani, A.J.P. (2016). Estimasi Curah Hujan Di Surabaya (Studi Kasus 12 Desember 2013, 26 Januari 2014 dan 20 Februari 2014). Prosding Egsa Fair.

Parwati, Suwarsono, Yulianto, F., Suprapto, T. (2008). Penentuan Nilai Ambang Batas untuk Potensi Rawan Banjir dari Data MT-SAT dan QMORPH. Jurnal Penginderaan Jauh, 5, 56-63.

SELEX. (2013). Software Manual Rainbow 5 Product \& Algorithms, SELEX SIGmbH, Germany.

Sudjana. (1996). Teknik Analisis Regresi Dan Korelasi, Tarsito: Bandung.

Suwarsono, P., Kusumaning, A.D.S., Kartasamita, M. (2009). Penentuan Hubungan Antara Suhu Kecerahan dangan MTSAT dengan Curah Hujan Data QMORPH. Jurnal Penginderaan Jauh, 6(1), 32-42.

Zakir, A. (2018). Analisa Cuaca. Jakarta: STMKG. 